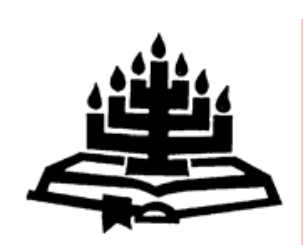

\title{
Hedendaagse wetenskaplike voorligting oor die verhouding tussen die manlike en vroulike geslag - 'n besinning oor die sosiobiologiese grondslae
}

\author{
B.J. van der Walt \\ Skool vir Filosofie \\ Potchefstroomkampus \\ Noordwes-Universiteit \\ POTCHEFSTROOM \\ E-pos: hanna@intekom.co.za
}

\begin{abstract}
Contemporary scientific guidance on the relationship between male and female - a reflection on its sociobiological foundations

A previous article discussed the ethical guidance given by contemporary popular books and articles on the relationship between men and women. The authority for Christians of such books (based on an evolutionist biology and worldview) was questioned. No answer was, however, provided on the important and difficult question whether and, if so, to what extent human biology influences or even determines one's ethical behaviour. Since many current books on sexual morality are based on empirical socio-biological research, this article takes a critical look at this scientific discipline. A Christianphilosophical alternative on the issue of human sexuality and gender will conclude this, as well as the previous article.
\end{abstract}

\section{Opsomming}

Hedendaagse wetenskaplike voorligting oor die verhouding tussen die manlike en vroulike geslag - 'n besinning oor die sosiobiologiese grondslae

'n Vorige artikel het die etiese voorligting ondersoek wat populêre boeke en artikels vandag oor die verhouding tussen mans en vroue bied. Die gesag wat sulke tipe werke (op 'n evolusionistiese biologie en lewensvisie gegrond) vir Christene het, is bevraagteken. Geen antwoord is egter nog gegee op die 
belangrike en moeilike probleem of, en indien wel, tot hoe 'n mate die menslike biologie sy etiese gedrag beïnvloed of selfs bepaal nie. Aangesien baie boeke oor seksuele moraal tans gebaseer is op empiriese sosiobiologiese navorsing, kyk hierdie artikel krities na hierdie wetenskaplike dissipline. Met 'n Christelik-filosofiese alternatief oor die vraagstuk van menslike seksualiteit en geslagtelikheid word hierdie, sowel as die vorige artikel, afges/uit.

\section{Ontstaan, vertrekpunte en inhoud van die Sosiobiologie}

In die vorige artikel is aangetoon hoe groot die invloed van die Darwinisme vandag sowel in die wetenskap as in die praktyk is. Die Westerse kultuur is besig om te "verdarwiniseer" (vgl. Aunger, 2001). Evolusionistiese idees wat vroeër meestal tot die biologiese wetenskappe beperk was, word vandag op gebiede soos die kuns, etiek, politiek, reg en godsdiens toegepas. Menslike kultuur word beskou as die blote produk van biologies-evolusionêre magte. 'n Nuwe wetenskap, die Sosiobiologie, het hierin 'n belangrike rol gespeel (vgl. Kaye, 1997). In die Sosiobiologie is die ouere Darwinistiese idee van eiebelang (die oorlewing van die sterkste) vervang met die "selfsugtige gene" (vgl. Dawkins, 1976 en Wright, 1994).

\subsection{Ontstaan}

Die Amerikaanse bioloog, E.O. Wilson, se boek Sociobiology (1975) word gewoonlik as die beginpunt van hierdie wetenskap beskou en hyself as die vader daarvan. Hoewel Wilson as Christen grootgeword het, kies hy reeds as student die evolusionisme as 'n beter verklaring van die werklikheid. (Vir biografiese gegewens, vgl. Pearcey, 2004:224 en Jochemsen, 2005:258.) Hy bepleit 'n humanistiese biologie (Wilson, 1982) en 'n naturalistiese lewensvisie (Wilson, 1994.) In laasgenoemde boek (Wilson, 1994:45) sê hy byvoorbeeld godsdiens en moraliteit "... had to be explained as material process, from the bottom up, atoms to genes to the human spirit. It had to be embraced by a single grand naturalistic image of man" (vgl. ook Wilson \& Ruse, 1991). Religieuse en etiese opvattings ontstaan dus nie van bo na onder (God of een of ander nie-materiële bron via die kultuur) nie, maar van onder na bo (van die mens se biologie na sy kultuur).

Van der Meer (2005:236) sê tereg dat die status van die verklarings van die Sosiobiologie of die Evolusionêre Psigologie (só genoem 
wanneer die Sosiobiologie op sedelike terrein toegepas word) afhanklik is van die status wat aan die evolusieteorie en evolusionistiese lewensvisie toegeken word. Oor laasgenoemde is reeds voldoende in die vorige artikel gehandel. Voordat die Sosiobiologie krities geweeg word, is dit nogtans nodig om iets meer oor die vertrekpunte en inhoud van dié wetenskap te sê.

\subsection{Vertrekpunte}

Wilson (1975:4) definieer die Sosiobiologie soos volg: “... the study of the biological basis of all social behaviour". Die uitgangspunt in hierdie wetenskap is dat alle menslike gedrag (kultuur) verklaar kan word uit die evolusionêre voorgeskiedenis van die mens, waarin natuurlike seleksie 'n belangrike rol gespeel het. Gedrag wat menslike oorlewing bevorder, bly voortbestaan. Wat 'n mens of groep as goed beskou (morele kodes), is in werklikheid die gedragsreëls wat uit die bestaanstryd gebore is. Die tipies evolusionistiese veronderstelling (al vanaf Darwin) word ook onderskryf, naamlik, dat hoewel die mens iets besonders is, hy/sy alleen gradueel en nie wesenlik van ander lewende organismes verskil nie. Die mens is slegs 'n hoër ontwikkelde dier.

Hoewel die toepassing van die evolusionisme op die menslike kultuur veral duidelik blyk uit Wilson se boek On human nature (1979), word hier enkele kerngedagtes uit sy grondliggende werk, Sociobiology (1975), gegee.

\subsection{Vrae en antwoorde}

Wilson (1975:565 e.v.) word ten opsigte van die evolusie van die mens met die volgende drie grondvrae gekonfronteer:

- Waarom het net 'n gedeelte van die voormenslike diere tot mense (homo sapiens) ontwikkel?

- Waarom kon hulle so ver bo hulle (niemenslike) voorgeslagte ontwikkel?

- Wat was die "trigger device" wat die proses veroorsaak het?

Soos te verwagte, word al hierdie fundamentele vrae slegs geneties en uit omgewingsfaktore "verklaar". Dieselfde metode word ook gevolg in die geval van die mens se sosiale lewe, taal, kuns, seksualiteit en godsdiens. 
Die groter plastisiteit en kompleksiteit van menslike sosiale omgang is bloot die gevolg van genetiese verskille tussen insekte, diere en die mens (Wilson, 1975:449-551). Hoewel menslike taal iets uniek is - 'n geweldige sprong in die evolusieproses (Wilson, 1975:556) - is dit ook (net soos die kunste) bloot 'n hoëre ontwikkeling van insekteen dieregeluide. Wilson (1975:559) kan egter nie verklaar waarom en wanneer presies menslike taal ontstaan het nie.

Vir hierdie ondersoek is veral Wilson se visie op godsdiens en seksualiteit belangrik - twee fasette wat nóú met mekaar saamhang:

\subsection{Godsdiens}

Godsdiens is volgens Wilson (1975:560) bloot die resultaat van 'n mens se omgewing en godsdienstige verskille die gevolg van omgewingsverskille. Die idee van 'n "morele God" wat die wêreld geskep het

... most commonly arises with a pastoral way of life. The greater the dependence on herding, the more likely the belief in a shepherd God of the Judaeo-Christian model ... Because the Hebrews were originally a herding people, the Bible describes God as a shepherd and the chosen people as his sheep (Wilson, 1975:560-561).

Dit gaan dus in godsdiens ten diepste om die stam/groep self, wat sy lede ter oorlewing van eie gene indoktrineer (Wilson, 1975:562). Op dié wyse "verklaar" Wilson waarom godsdiens - wat volgens hom meestal bedrog is - tog so 'n belangrike rol kan speel.

\subsection{Seksualiteit}

Volgens Wilson (1975:564) is "an evolutionary approach to ethics self-evident". Tussen al die moontlike soorte etiek kies hy 'n genetiese ontwikkelde of biologiese begronde etiek. "Scientists and humanists should consider together the possibility that the time has come for ethics to be removed from the hands of the philosophers and biologized" (Wilson, 1975:562).

So 'n "genetically accurate and hence completely fair code of ethics" (Wilson, 1975:574) kan egter eers - Wilson hoop binne 100 jaar bereik word, wanneer wetenskaplikes volledige kennis sal besit van die gene en die neurone van die menslike brein.

Dit beteken egter nie dat Wilson nie 'n duidelike standpunt oor seksualiteit en ander etiese probleme huldig nie. Hier volg enkele 
voorbeelde (Wilson, 1975): By die behandeling van geslagtelikheid (p. 314 e.v.) word slegs aan (biologiese) seks aandag gegee en nie aan geslagtelikheid (gender) nie. Fundamentele vrae soos waarom daar gewoonlik twee geslagte bestaan, word geneties verklaar (p. 316) en seksuele seleksie dien as verklaring waarom hulle verskil (p. 318). Sowel die verskynsel van poligamie as monogamie word op naturalistiese wyse verduidelik (p. 327 e.v.). Soos ook uit die vorige artikel geblyk het, word die manlike geslag as van nature poligaam beskou (p. 554). Ook homo-seksualiteit het bloot genetiese oorsake (p. 555).

Net soos by Pease \& Pease (2000) in die vorige artikel aangetoon is, erken Wilson (1975:563) ten slotte wel dat sekere vorme van biologies-gedetermineerde etiese gedrag nie meer by ons moderne omstandighede pas nie. Hy is egter daarvan oortuig dat nuwe morele kodes ook geneties geprogrammeerd behoort te wees.

Dit is duidelik waarom Pease \& Pease (2000) - vgl. vorige artikel hulle op die Sosiobiologie kon beroep om aan die publiek voorligting te gee oor hoe die twee geslagte verskil en hoe hulle hulle in ooreenstemming met hulle biologie behoort te gedra.

\section{Die Sosiobiologie: krities beskou}

Die Sosiobiologie is ná Wilson se boek ook deur ander wetenskaplikes verder ontwikkel en bevat ongetwyfeld waarheidsmomente. 'n Mens se biologie beïnvloed die res van jou menswees. ('n Chemiese wanbalans/-tekort kan byvoorbeeld tot ernstige depressie en selfs selfmoord lei.) Die groot probleem met die meeste sosiobiologiese werke is egter dat dit die fisies-chemiesbiologiese faset van menswees oorbeklemtoon en gevolglik al die ander fasette van die menslike bestaan daaruit probeer verklaar.

In hierdie afdeling word eers die evaluering van 'n psigoloog, bioloog en etikus (oorspronklik 'n molekulêre bioloog) gegee voordat enkele gevolgtrekkings gemaak word. Al drie hierdie skrywers veroordeel nie sumier die Sosiobiologie nie. Vanuit Christelikwetenskaplike perspektief probeer hulle sinvol daarop reageer.

\subsection{Van Leeuwen (1990)}

As psigoloog gaan Van Leeuwen (1990:18) in besonderhede in op die vraag of die verskille tussen die manlike en vroulike geslag alleen in die menslike biologie (seks) gegrond is, of dalk in die biologie sowel as die kultuur (nature en nurture). Indien al twee 
faktore in berekening gebring word, word dit 'n ingewikkelder probleem. Hoe sal bepaal kan word hoeveel van die (seksuele en geslags)verskille aan elkeen van die faktore toegeskryf moet word?

\subsubsection{Drie belangrike punte}

Daar is geen ander uitweg nie, om die volgende redes (vgl. Van Leeuwen, 1990:54):

- Mans en vroue is sowel biologies as psigies meer eenders as anders.

- (Biologiese) seks en (kulturele) geslagtelikheid beïnvloed mekaar wedersyds. Dit is nie so dat die nature die nurture beperk nie. Omgekeerd beïnvloed 'n mens se sosiaal-kulturele omgewing ook jou biologie.

- Keusevryheid, verantwoordelikheid en 'n besef van geslagtelike identiteit mag nie ontken word nie.

Hierdie drie punte word deur Van Leeuwen met talle voorbeelde geillustreer en bevestig. Daar bestaan volgens haar meer ooreenkomste as verskille tussen die twee geslagte. Soms is daar selfs meer verskille tussen mans/vroue van verskillende kulture as mans en vroue uit dieselfde kultuur.

Oor die verband tussen die gene en gedrag van die geslagte sê sy:

... while biology does not rigidly determine every detail of our behaviour, it is fair to say that in general, with individual variations, it can nuance that behaviour (Van Leeuwen, 1990:77).

Die resultaat met betrekking tot die derde punt hierbo is volgens haar veel ingewikkelder as wat die meeste populêre boeke dit voorstel. Die menslike verantwoordelikheid moet verstaan word in sy komplekse interaksie met sowel seks as seksualiteit (Van Leeuwen, 1990:78). Biologiese afwykings maak ongetwyfeld sekere vorms van gedrag meer waarskynlik (Van Leeuwen, 1990:81), maar selfs wanneer 'n (morele of ander) swakheid 'n genetiese basis het, ontneem dit volgens haar nie so 'n persoon van sy/haar verantwoordelikheid nie.

Van Leeuwen se ondersoek na hormone en die hemisfere van die brein lewer soortgelyke resultate op. Hoewel seksverwante hormone gedrag beïnvloed, gebeur dit nie volgens die gangbare stereotipering van mans en vroue nie, omdat die chemie van 'n 
mens se liggaam uitermate kompleks is en ook in hierdie geval mag hormone of die chemie van die brein nie as 'n verskoning vir onetiese (en selfs gewelddadige) gedrag gebruik word nie (Van Leeuwen, 1990:100, 101).

\subsubsection{Gevolgtrekking}

Van Leeuwen (1990:105) se konklusie lui soos volg:

$\ldots$ in al three areas we have examined - genes, hormones and hemispheres - we have found that the differences, when they occur, are both smaller and more complex than we thought. In most cases they are impossible to separate from the effects of learning. Moreover, we cannot invoke biology to excuse our moral failures as men and women. Our lives are permeated by a God-ordained freedom and accountability that works through, but at the same time transcends, our biological assets and liabilities.

\subsection{Van der Meer (2005)}

As bioloog toets Van der Meer die Sosiobiologiese wetenskap aan die hand van dié wetenskap se eie (evolusionistiese) voorveronderstellings. Om vir 'n evolusionistiese verklaring in aanmerking te kom, moet gedrag aan ten minste die volgende drie voorwaardes voldoen: erflikheid, variasie en 'n oorsaaklike verband tussen die twee asook die aantal nakomelinge (Van der Meer, 2005:237).

\subsubsection{Resultate}

Wat erflikheid betref, bevind Van der Meer (2005:239) dat die erflike invloed op moraliteit slegs indirek is. 'n Mens kan wel tot sekere gedragspatrone geneig wees, maar die spesifieke inhoud van die gedrag word deur die milieu (opvoeding) bepaal, byvoorbeeld alkoholverslawing. Ten opsigte van erflike variasie kan bewysmateriaal nie gelewer word nie, omdat die voorouers nie meer leef en 'n vergelyking met die huidige geslag dus nie moontlik is nie (Van der Meer, 2005:240). Die derde vereiste vir 'n evolusionistiese verklaring van morele gedrag is dat die lede van 'n bepaalde groep binne hulle normale omgewing spesifieke morele gedrag vertoon en as gevolg daarvan meer nakomelinge as ander groepe sou hê. Dit bevind Van der Meer (2005:241) onwaarskynlik.

Van der Meer ondersoek verder die veelbesproke kwessie van altruïsme - iets waarvoor evolusionistiese sosiobioloë (as gevolg 
van hul uitgangspunt van die oorlewing van die bes aangepaste) moeilik ' $n$ bevredigende verklaring kan vind. Sy algemene konklusie is "... dat evolutionaire verklaringen van moreel gedrag op dit moment volledig hypotetisch zijn" (Van der Meer, 2005:245).

\subsubsection{Drieërlei reduksie}

Samevattend is Van der Meer (2005:248 e.v.) se kritiek op die Sosiobiologie dat dit aan drie soorte reduksies mank gaan:

- Begripsreduksie: moraliteit word tot iets biologies gereduseer.

- Teoretiese reduksie: morele gedrag word alleen uit biologiese faktore verklaar.

- Werklikheidsreduksie: 'n naturalisties-materialistiese ontologie is die basiese vertrekpunt, wat behalwe vir biologiese (natuur)wette geen ruimte vir menslike norme het nie.

Van der Meer self dink antireduksionisties. Menslike moraliteit vereis volgens hom 'n verklaring waarin die wisselwerking tussen genetiese, neurale, kognitiewe, emosionele, sosiale, godsdienstige en ander faktore erken word (Van der Meer, 2005:250). Gene bepaal dus nie, maar beïnvloed slegs moraliteit via persoonlikheid, gevoel, intelligensie, en so meer. Moraliteit het volgens hom 'n multidimensionele karakter.

\subsubsection{Verantwoordelikheid}

Oor menslike verantwoordelikheid is Van der Meer (2005:254) se standpunt die volgende: 'n Ondersoek na die biologie van die mens bied wel kennis van die biologiese oorsprong en voorwaardes vir morele gedrag (die mens is immers 'n eenheid), maar nie oor goed en kwaad nie. Die spesifieke inhoud van morele gedrag is dus nie geneties vasgelê nie. Goeie gedrag het volgens Van der Meer nie 'n biologiese oorsaak nie. Omdat goeie gedrag nie van nature bestaan nie, moet dit (aan)geleer word. Morele (goeie of slegte) gedrag kan alleen op grond van sosiale, kulturele en religieuse gronde verklaar word. Dit verduidelik waarom verskillende kulture en godsdienste verskillende etiese norme voorstaan. Indien gedrag net biologies gedetermineer was, moes alle kulture en godsdienste ongeveer dieselfde norme gehuldig het.

\subsection{Jochemsen (2005)}

Soos die twee vorige skrywers, verwerp hierdie molekulêre bioloog en etikus ook nie by voorbaat die belang van die evolusionistiese 
etiek se bestudering van biologiese invloede op die menslike, spesifiek die etiese, gedrag nie. Die mens is immers ook 'n biologiese wese (Jochemsen, 2005:271). Jochemsen toets die sosiobiologiese teorieë en resultate en bevind, net soos Van Leeuwen en Van der Meer, dat hierdie teorieë ernstige tekortkominge het. (Omdat dit herhaling sou meebring, word hiermee volstaan.)

\subsubsection{Nie 'n volwaardige etiek nie}

'n Belangrike nuwe bydrae van Jochemsen (2005:260 e.v.) se artikel is sy fokus op etiek as wetenskap. Kom die etiek (as volwaardige wetenskap) in die Sosiobiologie tot sy reg? Jochemsen gee drie redes waarom dit syns insiens nie die geval is nie.

- Eerstens is gedrag in die algemeen en etiese gedrag nie dieselfde nie. Verskillende soorte gedrag (byvoorbeeld ekonomiese, juridiese, etiese, sosiale en godsdienstige gedrag) moet onderskei word. Een van die kenmerke van etiese gedrag is die vermoë om gedrag te evalueer of te waardeer. Organismes (soos insekte en diere) wat nie op dié wyse oor hulle eie optrede kan reflekteer nie, se gedrag kan dus nie as "eties" bestempel word nie. Dieregedrag kan dus nie as die basis vir menslike morele gedrag beskou word nie.

- Tweedens word die wetenskap Etiek nie as 'n onderafdeling van die biologie beskou nie (Jochemsen, 2005:272). Etiek is baie lank alreeds 'n selfstandige dissipline en behoort dit te bly.

- Derdens is die sosiobiologiese "etiek" ook 'n onvolledige "etiek".

\subsection{2 'n Onoplosbare dilemma}

Volgens Jochemsen (2005:271) word die evolusionistiese etiek met die dilemma gekonfronteer om óf deskriptief óf ook preskriptief te wees. Om bloot die bestaande te beskryf, beteken egter dat dit nie werklik 'n etiek is nie, aangesien dit tipies van dié vak is dat dit nie sonder meer bestaande gedrag as moreel goed aanvaar nie. Die ander opsie is dat die "moraal" wat deur evolusie gevorm is, korrek verklaar word en dat daar gevolglik van 'n beskrywende na 'n voorskrywende etiek oorgegaan word. In laasgenoemde geval word wat behoort egter uit die feitlike stand van sake afgelei (die sogenaamde naturalistiese drogredenasie). Dit sou onder andere beteken dat in die geval van abnormale menslike embrio's, prenatale aborsies gedoen mag word; of dat abnormale babas en vertraagde kinders om die lewe gebring mag word; of dat (veral) 
manlike promiskuïteit iets normaals is en as goed aanvaar moet word (vgl. die standpunt van Pease \& Pease en Wilson, soos vroeër beskryf).

\subsection{Enkele gevolgtrekkings}

Behalwe die kritiek wat alreeds in die voorafgaande gedeeltes gelewer is, is die volgende gevolgtrekkings oor die evolusionistiese Sosiobiologie van belang:

- Dit is tot veralgemening (stereotipes) geneig.

- Behalwe dat dit reduksionisties is in die sin wat alreeds onder 2.2.2 genoem is, is dit ook reduksionisties in dié sin dat dit belangrike historiese en kulturele variasies in seksuele morele gedrag ignoreer.

- Bewysvoering is in baie gevalle op die studie van dieregedrag gebaseer. Die groot verskille tussen mens en dier word dus nie voldoende in berekening gebring nie.

- Sosiobioloë probeer komplekse menslike gedrag verklaar deur 'n eenvoudige beroep op evolusionistiese aanpassings vir oorlewing en geskiktheid wat in die vervloë verlede sou plaasgevind het. Gevolglik kan sosiobiologiese teorieë nie werklik getoets word nie. (Sosiobioloë se teorieë begin byvoorbeeld met die observasie dat mans aggressiewer as vroue is. Hiervandaan werk hulle dan miljoene jare terug om 'n "verklaring" vir die huidige gedrag te voorskyn te roep.)

- Sosiobioloë maak van metodes gebruik wat verantwoordelike bioloë en ander wetenskaplikes as gebrekkig sou bestempel. Daar word byvoorbeeld beweer dat mans vandag nog in hulle gene die feit saamdra dat hulle oorspronklik as jagters die voedsel moes voorsien, sodat hulle gesin/groep kon oorleef. Antropoloë, wat die eetgewoontes van primitiewe mense bestudeer, het egter vasgestel dat jag maar 'n sporadiese aktiwiteit was. Die grootste hoeveelheid voedsel is daagliks deur die vroue versamel.

Indien die Sosiobiologie in die lig van die voorafgaande, nie as 'n betroubare gids beskou kan word om die morele gedrag by mans en vroue te bepaal nie, is daar 'n alternatief? 


\section{Die breë lyne van 'n alternatiewe, Christelike perspektief}

By die uitwerk van die volgende perspektiewe, is die skrywer veral deur die geskrifte van Storkey (2001), Van Leeuwen (1990) en Verkerk (1997) gestimuleer. (Die belangrike publikasies van Clayton en Schloss (2004) en Jeeves (2004) is ongelukkig eers na die afhandeling van hierdie artikel ontdek.) Eers word enkele basiese Bybelse perspektiewe behandel. Daarna volg 'n aanduiding van hoe dit wetenskaplik uitgebou kan word. In 'n samevattende slotperspektief word teruggekeer na die twee belangrike vrae waarvoor die Sosiobiologie nie 'n oplossing kon bied nie.

\subsection{Basiese Bybelse perspektiewe}

Van Leeuwen (1990:34-51) dui aan hoe belangrik die basiese Bybelse perspektiewe van skepping, sondeval en verlossing ook vir die huidige vraagstuk is. Reeds in die eerste drie hoofstukke van Genesis kom fundamentele gesigspunte na vore.

\subsubsection{Skepping}

By die skepping is die volgende in verband met die man en die vrou duidelik:

- hulle ooreenkomste,

- hulle verskille, en

- hul komplementariteit of aanvulling van mekaar.

\section{- Ooreenkoms}

Uit Genesis is dit duidelik dat, aangesien hulle albei mense is, man en vrou meer eenders as anders is. Adam vind onder die diere waarvoor hy name moet gee nie een soos hy, sy gelyke nie (2:20). Die vrou word ook uit die man geskep (2:21) en Adam erken dat die vrou - anders as die diere - een soos hy is (2:23). Albei is na die beeld van God geskep (1:27), hulle kry dieselfde kultuuropdrag $(1: 28)$ en albei moet volgens God se gebod lewe $(2: 16)$. Hierdie perspektief word in die res van die Bybel (bv. by die Pinkstergebeure, vgl. Hand. 2 en ook Gal. 3:28) bevestig.

\section{- Verskil}

Dieselfde hoofstukke in Genesis ontken egter nie geslagtelike verskille nie. Eva is, hoewel Adam se gelyke, iemand anders, 
iemand wat as helper sy menswees kan aanvul. Sy kry 'n ander naam, Eva, en word uitdruklik vrou genoem (Gen. 2:23).

Hoe belangrik dit is om hierdie eerste twee Bybelse perspektiewe sáám te handhaaf, word duidelik by verskillende feministiese bewegings (vgl. Verkerk, 1997:59 e.v.). Die vroeëre feministiese bewegings wou die vrou bevry deur die verskille tussen die geslagte te beklemtoon, terwyl 'n tweede feministiese golf die klem op die ooreenkomste gelê het. Dit word in meer detail behandel deur Storkey (2001). Waardevol in dié verband is ook Van Leeuwen (1993) en Stuart en Thatcher (1996).

\section{- Komplementariteit}

Die verskil in ooreenkoms/die ooreenkoms in verskil kom saam in die derde Bybelse perspektief van die komplementariteit van die geslagte na vore. Uit Genesis is dit duidelik dat God se skepping onafgehandel sou gewees het sonder die vrou. Daar word uitdruklik gesê dat dit nie goed was dat die man alleen is nie (Gen. 2:18). Ook Adam self voel 'n gemis (Gen. 2:20). Dus ontvang Adam van die Here iemand wat anders en tog eenders is - ' $n$ helper.

Die woord helper dui op die komplementêre verhouding tussen die twee geslagte. Uit die res van die Skrif is dit duidelik dat die vrou nie net die man moet "aanvul" nie, maar dat die omgekeerde ook die geval behoort te wees. Die woord helper moet ook nie só verstaan word dat Eva Adam se ondergeskikte is nie. Nie haar minderwaardigheid nie, maar eerder haar onontbeerlikheid is duidelik. Dit blyk byvoorbeeld uit die feit dat die woord helper (ezer) meestal van God (as die mens se Helper) gebruik word (bv. Ps. 121:2). Daaruit mag tog nie die gevolgtrekking gemaak word dat God die mindere van die mens is nie (Van Leeuwen, 1990:42).

Verkerk (1997:217) verduidelik:

Centraal staat de daad, het helpen, het ondersteunen. Het karakteriseert de activiteit, niet de identiteit van die helper. Het duidt erop dat de mannelijke mens alleen tot zijn bestemming kan komen als hij ondersteund wordt door de vrouwelijke mens. $\mathrm{Hij}$ is afhankelijk van haar. Hij kán het niet alleen. En zij? Zij is geschapen in betrokkenheid op hem. Juist in de man-vrou relatie zien we het aspect van wederzijdse afhankelijkheid en betrokkenheid duidelijk naar voren tree.

(Vgl. ook Van Leeuwen, 1990:42 en Storkey, 2001:130 in hierdie verband.) 
Dit is belangrik om daarop te let dat die wedersydse aanvulling nie net op die huwelik van toepassing is nie. Ook buite die getroude lewe moet die twee geslagte - al is dit op ander maniere as in die huwelik - mekaar komplementeer. Om die unieke van die huweliksverhouding duidelik te maak, gebruik Storkey (2001:131), behalwe die "paradigmas" van ooreenkoms, verskil en aanvulling ook 'n vierde, naamlik eenheid. Man en vrou word in die huwelik so één dat hulle nie meer alleen oor hulle seksualiteit mag beskik nie. Hulle moet ook wedersyds aan mekaar onderdanig wees (Ef. 5:21).

Met die sondeval het die situasie egter heeltemal verander.

\subsubsection{Sondeval}

Soos wat die sonde alles in die skepping aangetas het, word ook die drie basiese riglyne (ooreenkoms, verskil en aanvulling) in die verhouding van die geslagte van mekaar losgemaak en dus verdraai.

Die ooreenkomste word van die verskille geskei en gevolglik as eendersheid gesien, óf die verskille word op sigself gestel en dus oorbeklemtoon, wat tot die bekende stereotipes oor die geslagte lei. In nie een van die twee gevalle kan die derde, Bybelse beginsel van komplementariteit, dus tot sy reg kom nie.

Uit Genesis 3 blyk duidelik dat disharmonie en verkeerde kompetisie in die plek van wedersydse hulp en aanvulling gekom het. Adam plaas die skuld op Eva (3:12). Eva se begeerte is nog na Adam, maar hy wil haar nie meer aanvul nie, maar oorheers (3:16b).

Dit is dalk die rede waarom Olthuis (1997:146) in plaas van komplementariteit liewer wederkerigheid (mutuality) as norm vir die verhouding van die twee geslagte beskou. Dit moet as korreksie dien vir die selfgesentreerdheid wat na die sondeval by die man en die vrou ingetree het.

Van Leeuwen (vgl. 1990:44) beweer selfs dat die wyse waarop God man en vrou straf, aansluit by hulle geslagtelikheid. In die geval van die man verander (gesonde) heerskappy oor die skepping in (verkeerde) oorheersing oor die vrou en die res van die skepping. In die geval van die vrou verander haar sosiale karakter (sociability) in sosiale verstrengeling (social enmeshment). 


\subsubsection{Verlossing}

Verlossing in Christus beteken dat die mens in die krag van die Heilige Gees daarna kan streef om weer volgens die oorspronklike skeppingsriglyne te lewe. Ook die vrou se straf (naamlik dat die man oor haar sal heers) moet verander. (Die feit van God se straf mag nie as 'n norm beskou word nie.) Wat die uiteindelike lewe op 'n nuwe aarde betref, sê die Bybel wel dat die huwelik dan nie meer nodig sal wees nie. Omdat God se verlossing herskepping beteken, impliseer dit egter nie noodwendig dat geslagtelike verskille sal verdwyn nie.

\subsection{Verdere wetenskaplike uitwerking nodig}

Sover nagegaan kon word, is bogenoemde perspektiewe oor geslagtelikheid nog nie in detail wetenskaplik uitgewerk en toegepas nie. Verkerk (1997:201 e.v.) het op Christelik-filosofiese gebied 'n eerste stap in dié rigting gewaag.

In die eerste plek besin hy oor die sin van geslagsverskille. Die hele skepping het sin, omdat dit onselfgenoegsaam is (van God afhanklik is) en dus na Hom heenwys. Maar ook die geskape dinge is onderling wedersyds van mekaar afhanklik en by mekaar betrokke om sodoende mekaar aan te vul. (Vgl. die reeds genoemde perspektief van komplementariteit tussen die geslagte.)

In die tweede plek bied Verkerk ook (vanuit die filosofie van $\mathrm{H}$. Dooyeweerd) 'n breër antropologiese basis vir die kwessie van seksualiteit en geslagtelikheid. Daarvolgens bestaan menswees uit ongeveer vyftien modaliteite. Met hierdie mensbeskouing word die eendimensionele, naturalistiese mensvisie van die Sosiobiologie met 'n multidimensionele mensbeskouing vervang. Seks het betrekking op die vroeëre modaliteite (getalsmatige, ruimtelike, fisiese, chemiese en biologiese). Geslagtelikheid het betrekking op die latere modaliteite of aspekte wat op die biologiese volg (die psigiese, logiese, historiese, linguale, sosiale, ekonomiese, estetiese, juridiese, etiese en pistiese).

Terwyl die latere modaliteite in die vroeëre gefundeer is, word die vroeëre modaliteite weer in die latere modaliteite ontsluit. Op hierdie wyse word verklaar waarom daar wedersydse beïnvloeding tussen seks en geslagtelikheid is, terwyl elkeen tog 'n eie karakter het.

Afgesien daarvan dat die mens funksioneel veel ryker is as diere, is daar nog 'n radikaler (pre-funksionele) verskil: die mens is na die beeld van God geskep, 'n religieuse wese. Dit impliseer onder 
andere dat hy/sy tussen goed en kwaad kan onderskei en dus verantwoordelik is om God se sentrale liefdesgebod te gehoorsaam (vgl. byvoorbeeld Stafleu, 1991:101 e.v.).

\section{Samevattende slotperspektief: die roeping van man en vrou}

Die Sosiobiologie probeer om (veral in die Evolusionêre Psigologie) ' $n$ antwoord op twee belangrike vrae te gee: Wat is die verskil tussen die twee geslagte?, en Hoe weet 'n mens dat jy jou as man/vrou reg gedra? (vgl. byvoorbeeld Wilson, 1975:316-318).

'n Christelike antwoord op die eerste probleem het alreeds in die voorafgaande bespreking aan die orde gekom. Manlike en vroulike seks, seksualiteit en geslagtelikheid verskil, maar kom ook ooreen. Die bedoeling is dat die twee geslagte mekaar sal komplementeer. Dit is ' $n$ veel ryker antwoord as dié wat vanuit 'n evolusionistiese perspektief gebied kan word.

Die antwoord op die tweede, meer praktiese vraag, naamlik hoe die twee geslagte moet optree, moet ten slotte nog breër uitgewerk word.

\subsection{Antwoorder, amp, roeping}

Verkerk (1997:209 e.v.) gaan van die gedagte uit dat die mens in alles wat hy/sy doen op God se Woord moet antwoord. Menswees beteken ten diepste om "antwoorder" te wees (vgl. ook Buijs et al., 2005). Antwoord impliseer ook ver-antwoord-elikheid. Omdat die twee geslagte uniek is, het hulle verantwoordelikhede egter ook 'n besondere, eie karakter.

Van Leeuwen (1990:70) se gedagte sluit hierby aan. Haar vertrekpunt is dat God die mens tot verskillende ampte roep. Die belangrikste, omvattende amp is vir albei geslagte die amp van liefdevolle diens in die alles-insluitende koninkryk van God. Daarbenewens is daar "sekondêre" ampte, soos dié van ouers ('n man word vader en 'n vrou word moeder), van die owerheid en nog meer. Die spesifieke amp van man- en vrouwees is "to express complementarity and mutuality" (Van Leeuwen, 1990:70).

Bogenoemde twee gedagterigtings word deur die artikelouteur saamgevat in die gedagte van roeping. Die roeping van manwees en vrouwees moet uitgevoer word in die lig van die drie basiese Bybelse perspektiewe van ooreenkoms, verskil en aanvulling. 


\subsection{Drie riglyne}

Die eerste riglyn (ooreenkoms) beteken dat die roeping van die man nie hoër of belangriker is as dié van die vrou of omgekeerd nie (vgl. Gal. 3:28 en Kol. 3:11). Soos hierbo aangedui, het albei 'n primêre roeping in die koninkryk van God en daarna ook 'n roeping in verskillende samelewingsverbande (bv. dié van ouers in die gesin, of owerheid en onderdaan in die staat, ensovoorts).

Die roepingsgedagte mag egter nie die belangrike feit ignoreer dat elke mens 'n unieke persoon met unieke gawes en talente is nie. Bowendien moet elke mens (man én vrou) sy/haar roeping onder unieke omstandighede volbring.

Die implikasie van die tweede riglyn (naamlik verskille in seks, seksualiteit en geslagtelikheid) is dat man en vrou hulle onderskeie roepings nie op identiese wyse kan of mag uitvoer nie. Fowler (2004:5) sê tereg:

The rejection of gender stereotypes does not involve a denial of gender differences. It simply celebrates the rich complexity and diversity of the human person in both its female and male forms.

Ook die derde riglyn mag nie verwaarloos word nie. Komplementariteit bring sowel die ooreenkomste as die verskille tussen die geslagte tot 'n sintese, op 'n derde vlak van roepingsvervulling. Dit relativeer die geslagtelike verskille, sodat die geslagte (op grond van hulle verskille) mekaar nie sal beveg of in ongesonde kompetisie verval nie. Die ooreenkomste tussen die geslagte mag ook nie oorbeklemtoon word, sodat die verskille geïgnoreer word nie. Ook die basiese eendersheid moet gerelativeer word, sodat die geslagte mekaar kan komplementeer.

\subsection{Nie voorskriftelik nie}

Bly dit nie nog steeds te abstrak nie? Kan 'n mens nie meer spesifiek wees oor die wyse waarop die man en die vrou hulle roeping moet vervul nie?

Die skrywer meen dat indien nie hiermee volstaan word nie, stereotipering van die roepingsgedagte 'n wesenlike gevaar word. Weens die komplekse wisselwerking tussen seks, seksualiteit en geslagtelikheid, kan nie meer gesê word nie; en weens die uniekheid van elke man en vrou en elke situasie mag 'n mens ook nie voorskriftelik wees nie. 
Elke mens het sy/haar eie geheim. Olthuis (2005:77) sê tereg: "Each of us is a non-exchangeable, ultimately mysterious, unspeakably precious, unique person ...". Elke vrou/man sal dus coram Deo (voor die aangesig van God) moet uitmaak wat haar/sy spesifieke roeping behels. Net so moet elke man/vrou, met inagneming van hulle unieke aanleg, gawes en omstandighede, self besluit hoe hulle God en hulle medemens die beste kan dien. Olthuis stel dit weer raak:

Each of us, male or female, in our singular and particular destinies are called to work out what it means that we are generically men or generically women ... belonging to a gender represents a universal that exists prior to me. I have to accomplish it in relation to my particular destiny (Olthuis, 2005:78).

\section{Geraadpleegde bronne}

AUNGER, R., ed. 2001. Darwinizing culture. Oxford: Oxford University Press.

BUIJS, G., BLOKHUIS, P., GRIFFIOEN, S. \& KUIPER, R., reds. 2005. Homo respondens. Amsterdam: Buijten \& Schipperheijn.

CLAYTON, P. \& SCHLOSS, J., eds. 2004. Evolution and ethics: human morality in biological and religious perspective. Grand Rapids: Eerdmans.

DAWKINS, R. 1976. The selfish gene. New York: Oxford University Press.

FOWLER, S. 2004. On being human: towards a Biblical understanding. Melbourne: Amani Educational Services.

JEEVES, M., ed. 2004. From cells to souls - and beyond: charging portraits of human nature. Grand Rapids: Eerdmans.

JOCHEMSEN, H. 2005. Sociobiologie, mensbeeld en ethiek. (In Dekker, C., Meester, R. \& Van Woudenberg, R., reds. Schitterend ongeluk of sporen van ontwerp? Over toeval en doelgerichtheid in de evolutie. Kampen: Ten Have. p. 255-272.)

KAYE, H. 1997. The social meaning of modern biology: from Darwinism to Sociobiology. New Brunswick: Transaction.

OLTHUIS, J.H. 1997. Face-to-face: ethical asymmetry or the symmetry of mutuality? (In Olthuis, J.H., ed. Knowing otherwise: philosophy at the threshold of spirituality. New York: Fordham University Press. p. 131-158.)

OLTHUIS, J.H. 2005. The miracle of mutual love: Luce Irigaray and the ethics of sexual difference. (In Kok, J.H., ed. Ways of knowing in concert. Sioux Center: Dordt College Press. p. 71-84.)

PEARCEY, N.R. 2004. Total truth: liberating Christianity from its cultural captivity. Wheaton: Crossway Books.

PEASE, B. \& PEASE, A. 2000. Why men don't listen and women can't read maps: how we are different and what to do about it. New York: Broadway Books.

STAFLEU, M.D. 1991. Being human in the cosmos. Philosophia Reformata, 54:101-131.

STORKEY, E. 2001. Origins of difference: the gender debate revisited. Grand Rapids: Baker Book House. 
STUART, E. \& THATCHER, A. 1996. Christian perspectives on sexuality and gender. Grand Rapids: Eerdmans.

VAN DER MEER, J. 2005. De biologie van moreel gedrag: een keuse uit feiten en ficties. (In Dekker, C., Meester, R. \& Van Woudenberg, R., reds. Schitterend ongeluk of sporen van ontwerp? Over toeval en doelgerichtheid in de evolutie. Kampen: Ten Have. p. 235-254.)

VAN LEEUWEN, M.S. 1990. Gender and grace: love, work and parenting in a changing world. Downers Grove: InterVarsity.

VAN LEEUWEN, M.S. 1993. After Eden: facing the challenge of gender reconciliation. Grand Rapids: Eerdmans.

VERKERK, M. 1997. Sekse als antwoord. Amsterdam: Buijten \& Schipperheijn.

WILSON, E.O. 1975. Sociobiology: the new synthesis. Harvard: Harvard University.

WILSON, E.O. 1979. On human nature. New York: Bantam Books.

WILSON, E.O. 1982. Toward a humanist biology. The Humanist, 40-50, Sept./Oct.

WILSON, E.O. 1994. Naturalist. Washington: Island.

WILSON, E.O. \& RUSE, M. 1991. The evolution of ethics. (In Hutchingson, J.E., ed. Religion and the natural sciences: the range of engagement. Orlando: Harcourt \& Brace. p. 300-310.)

WRIGHT, R. 1994. The moral animal: why we are the way we are. New York: Vintage.

\section{Kernbegrippe:}

etiek (evolusionêre)

evolusionisme

geslagtelikheid

seksualiteit

Sosiobiologie

Wilson, E.O.

\section{Key concepts:}

ethics (evolutionary)

evolutionism

gender

sexuality

Sociobiology

Wilson, E.O. 